\title{
LA AUTORÍA FEMENINA Y LA CONSTRUCCIÓN DE LA IDENTIDAD EN CRÓNICA DEL DESAMOR DE ROSA MONTERO
}

\author{
Shirley Montero Rodríguez
}

\begin{abstract}
RESUMEN
La reflexión de este trabajo establece la posibilidad de descubrir un lugar para la literatura escrita por mujeres, donde esta se construye mediante elementos propios del espacio femenino, con su específica visión del mundo a partir de sus circunstancias de vida. En primer lugar, se presentarán los aspectos preliminares que ubicarán este trabajo en cuanto a las coordenadas históricas, culturales y sociales más importantes, las cuales permitan manejar un panorama global de la producción literaria femenina en España, durante el último cuarto del siglo XX. También, se unirá a este apartado la perspectiva teórica, como marco de reflexiones generales. En un segundo apartado, se pretende realizar el análisis textual, para establecer la configuración discursiva de la voz autoral femenina. Palabras clave: literatura femenina, identidad, autoría, narrativa española, Rosa Montero.
\end{abstract}

\begin{abstract}
The reflection of this work establishes the possibility of discovering a place for literature written by women, explicitly when it is constructed by means of elements proper of the feminine space, with its specific world perspective and from its own circumstances in life. First, it will present the preliminary aspects that will locate this work in the most important historical, cultural and social context. This may allow to handle a global panorama of feminine literature production in Spain, during the last quarter of the XXth Century. Furthermore, the theoretical perspective will be joined in this section, as a frame for general reflections. In the second section, it is intended to formulate an analysis, so to establish the discursive configuration of the voice of feminine authorship.

Key words: feminine literature, identity, authorship, Spanish narrative, Rosa Montero.
\end{abstract}

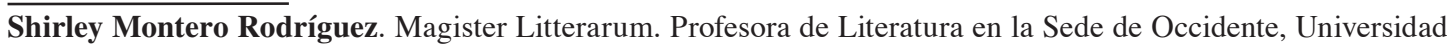
de Costa Rica.

Correo electrónico: shirleymr02@costarricense.cr

Recepción: 08-6-2007

Aceptación: 29-7-2007 


\section{Introducción: Contexto socio-histórico de la nueva narrativa femenina española}

Para hablar de literatura, como producto cultural, es indispensable hablar del fenómeno social que le rodea. En ese sentido, para comprender un poco mejor la narrativa femenina en la España contemporánea, obligatoriamente, hay que adentrarse en los hechos históricos que marcaron esta nación durante gran parte del siglo XX, y que se puede resumir en el régimen del general Francisco Franco. Durante el período que comprendió los años 19391975, la sociedad española mantuvo una normatividad en la vida cotidiana, que marcaría el pensamiento y la educación de la mujer y del hombre:

\footnotetext{
Para los hombres y la mujeres españolas el régimen franquista, por su extensión en el tiempo, ha supuesto no sólo vivir de una forma diferente durante un largo período sino tener ahora mismo una herencia social y cultural donde la tradición; los mandatos de la Iglesia o la concepción tradicional del papel social de los hombres y las mujeres aún tiene un peso, cada vez menor, eso sí, pero aún mucho mayor del que esos mismo condicionantes tienen actualmente en otros países de nuestro entorno cultural y económico (Bosch et al. 1999:191).
}

La inserción de los valores del pasado (especialmente culturales y religiosos), acerca de los roles de género, fue tan profunda que aún tiene influencia en la sociedad actual, y los escritores españoles contemporáneos todavía pretenden eliminar.

La condición de censura implicaba una mayor carga social hacia la mujer, pues con el fin de la Guerra Civil y el triunfo nacional, en 1939, el pueblo español acentuó una serie de reglas morales que la orillaban a un plano casi invisible de la vida social, convirtiéndose en una sombra. Estrategia defendida por José Antonio Primo de Rivera1, cuando dice que: "Las mujeres no harán más que redoblar con su voto el voto masculino, con sus defectos; no teniendo por tanto, el de ellas trascendencia en el camino futuro de España...” (Bosch et al. 1999: 177). Con esto queda claro el papel secundario de la mujer no solo en el espacio público, sino en el privado también. Así como la nulidad de su pensamiento, la incapacidad de tomar decisiones o de tener una participación política que no fuese la de seguir a sus padres o maridos.

La educación de la mujer y su vida entera son orientadas a la maternidad, fragilidad, sumisión, y espíritu de sacrificio, valores eternos y que durante el régimen se promueven y reinstauran bajo diversos mecanismos sociales coercitivos. El primero, y quizá más importante, de esos mecanismos lo constituyó la Sección Femenina de la Falange² Española, fundada en 1934 bajo la jefatura de Pilar Primo de Rivera, y que funcionó hasta 1977.

La Sección Femenina se encargaba de la educación de las mujeres en el nuevo gobierno nacionalista, así como de mantener la denominada "moral" que consistía en el discurso del recato, tal como la mesura en la vestimenta (incluido el uso riguroso de las medias), supresión del maquillaje, de posturas poco honestas y del fumado. Durante la guerra, el trabajo de la mujer consistía en servir de apoyo en el cuidado de heridos y soldados. En síntesis, el objetivo ideológico era formar un modelo de mujer que se caracterizaba por su sumisión al hombre, y su preparación para cumplir sus misiones básicas: esposa y madre.

Más que un medio de educación, la Sección Femenina de la Falange era un verdadero medio de control y represión social, que se veía fomentado por el Servicio Social obligatorio, bajo el decreto 378 del 7 de octubre de 1937. Toda mujer debía prestar su apoyo en hospitales e instituciones militares, pero sólo en labores propias para ella: cocinar, lavar, coser, etc. Se descartaba toda posibilidad laboral y profesional reales: "A partir de 1942 todas las reglamentaciones de trabajo comenzaron a disponer que las mujeres, al casarse, debían abandonar su puesto de trabajo" (Bosch et al. 1999: 164-182). 
La educación de las niñas quedaba reducida a la formación preparatoria para el hogar. En 1939 quedaron suprimidas las escuelas mixtas, y se instaura una estrecha censura privada, la cual debían atravesar todos los materiales educativos. Finalmente, las materias educativas para las niñas quedaban reducidas a Hogar, Higiene, Floricultura, Cocina, Corte y confección, Economía doméstica, etc. (Bosch 1999: 187 y 188).

Con estas medidas socio-políticas se garantizaban dos procesos importantes: por una parte, el trabajo de los hombres y la reclusión de la mujer al ámbito privado del hogar; y en segundo lugar, la educación de los hijos bajo estos principios morales. La madre sólo servía como canal para transportar a los hijos, los valores morales concernientes al comportamiento público y privado, dentro del régimen. Estos valores por supuesto eran dados por los hombres.

En este estrecho panorama que ofrecía la España franquista, y que en mucho era respaldada con la moral promulgada por la Iglesia Católica, queda claro el nivel insignificante de la mujer, tanto en el desempeño social como personal, y la nulidad de su intelecto. Aunque ya a partir de 1952, con el I Congreso Nacional de Justicia y Derecho, se inicia el lento proceso de cambio, mucho de eso sólo quedaba en el papel, pues en la práctica todavía la mujer sólo ganaba un $80 \%$ del salario del hombre en igual desempeño. Así, por mucho tiempo la mujer se vio determinada por una enorme carga social vinculada con su género, la cual le impedía la transición a otro plano que no fuera el de madre o esposa.

Precisamente, en este panorama histórico español se reconocen los mismos mecanismos culturales de coerción de la mujer, que han existido desde hace siglos en cualquier otro país del mundo. Sin embargo, aquí son más evidentes, contundentes, y si se quiere más agresivos por estar explicitados bajo normas legislativas.

Con la muerte de Franco y el inicio de la etapa democrática en España, la nueva narrativa española también sufrió un proceso de cambio, que abarcó los años de 1978 a 1982. Durante este período se busca reconstruir un pasado nostálgico:

\footnotetext{
...por lo menos en parte, el malestar o el desencanto que prevalece en el ámbito de los escritores de la transición los sitúa en un espacio contradictorio entre la osificación de un discurso político cultural del pasado, un materialismo cínico del presente, y un deseo de deconstruir y reconstruir esos huesos secos cada vez más desprovistos de significación para el futuro (Ordóñez 1995: 172).
}

De acuerdo con esto, ¿qué podría esperarse de la narrativa escrita por mujeres? También sufre ese desencanto, en cuanto se percibe como una búsqueda de la desmitificación. Las escritoras pretenden deshacer el encanto, o encantamiento, es decir el "mito" largamente acuñado durante el período dictatorial. Pero, su mutilación ha sido mayor y han sufrido tal proceso de aislamiento que se perfila como un camino de emergencia mucho más lento, hasta llegar al momento del destape: se retoman temas tabú, se publicita lo privado, y se denuncia la ya inaceptabilidad de esa rigurosa normativa de sujeción de la mujer. Ordóñez explica de esta forma la situación:

... el dilema que silenciaba a las mujeres durante los primeros años de la democracia se debía a que el espejo de nuestra opresión está poblado por el lenguaje del hombre. De ahí nuestra dificultad en romper a hablar (Ordóñez 1995: 173).

La narrativa femenina se iba a marcar como un ámbito marginal, como lo "raro" o lo "anormal", o se refugiaba en lo íntimo. Todo esto en una sociedad tan notoriamente androcéntrica, bajo el deseo de uniformidad que distingue a todo sistema político, y donde 
no se da cabida a nada que se salga de la norma. No es extraño que sean muchos los nombres de autores españoles contemporáneos que nos llegan aquí, al otro lado del mar. Entre los que podemos destacar a: Juan Goytisolo, Camilo José Cela, Antonio Muñoz Molina, Julio Llamazares, Eduardo Mendoza, Manolo Vásquez Montalbán, Gonzalo Torrente Ballestero, Juan Marsé, entre otros. Sin embargo, es relativamente poca la mención que se hace de escritoras españolas.

Ese fenómeno resulta más interesante, cuando al indagar un poco se descubre un descomunal número de autoras españolas contemporáneas, entre las que destacan periodistas, novelistas y cuentistas: Mariana Mayoral, Carmen Riera, Carmen Gómez Ojeda, Lourdes Ortiz, Ana María Matute, María Jaén, Mercedes Abab, Ana Rossetti, Concha Alós, Cristina Fernández Cubas, Paloma Díaz-Mas, Carmen Martín Gaite, Adelaida García Morales, Marta Portal, Monserrat Reing, Esther Tusquets, Ana Moix, Luisa Echenique, María Antonia Oliver, Mercé Rodoreda, Rosa Chancel, Emilia Pardo Bazán, Soledad Puértolas y Rosa Montero, entre otras. La mayoría de ellas ha desarrollado el género novelístico, especialmente la novela lírica o íntima, ya que por su naturaleza y características, es donde se les ofrece más posibilidades de investigar y profundizar su devenir histórico-cultural, y más importante aún, sobre la configuración de una identidad propia, que por mucho tiempo les fue negada (Pérez Pisonero 1991: 129).

\section{Aproximación teórica: Literatura y género}

Al hablar de literatura femenina estamos de antemano determinando el ámbito al que nos circunscribimos: "...hay una totalidad, la llamada creación literaria en general que no lleva signo de lo femenino y que en ausencia lleva el de su signo contrario, el de lo masculino" (Mora et al. 1985:21).

En la cultura ha predominado esa lógica binaria hombre/mujer, en todos los campos, donde se da una jerarquía disimulada que genera posiciones desventajosas para la mujer; ya que lo subordinado es lo femenino, y lleva a la literatura escrita por mujeres a constituirse en una lectura desde la marginalidad. Desde aquellas tachaduras, omisiones o silencios que impuso la sociedad patriarcal porque amenazaban en convertirse en cuestionadoras del orden establecido. Lo que justifica, precisamente, las experiencias íntimas que tematizan.

Luce Irigaray, en su texto Ese sexo que no es uno, aborda la perspectiva freudiana, donde lo femenino se presenta como la ausencia del sexo masculino, como la negación. La mujer es "el no ver", por lo que privilegia lo táctil; en tanto que el hombre privilegia la mirada sobre la mujer, pues es lo completo: “...el otro sexo no es más que el complemento indispensable del único sexo (el masculino)” (1982: 27).

Se presenta a la mujer como la alteridad, como la negación, y por ello se le atribuyen patologías como: frigidez, histeria, masoquismo, complejo de virilidad, envidia del pene. Pero, según Irigaray no se observa la pluralidad que implica la sexualidad femenina; de hecho no se le da un lugar a dicha sexualidad que no sea la de revés de lo masculino. La feminidad es negada por lo fálico, y no reconocida como un tú diferente, sino como una imagen reflexiva del hombre.

En cuanto a la economía, Irigaray establece que la mujer ha pasado a ser un objeto del intercambio comercial entre los hombres, siendo despojada de la palabra. Es así como 
la mujer carece de nombre propio que la identifique como individuo (siempre es "hija de...", "esposa de...", o "viuda de..."), y adquiere un valor natural (su cuerpo) y un valor social (asignado por los hombres en función de sus intercambios).

A la mujer se le ha negado la autodefinición y se le ha configurado como lo mimético. Por ello, Irigaray propone asumir el discurso falócrata para desde él, impugnarlo y cuestionarlo. El lenguaje considerado como lógico-sintáctico es el del discurso patriarcal, el lenguaje considerado ilógico-intuitivo es el de la mujer; pues de ella es el monólogo interior, lo reprimido, lo inarticulado, lo subjetivo, y por ello lo carente de todo valor social. Por eso, se debe escapar del discurso falocéntrico desde él mismo: "Se trata de asumir, deliberadamente, este rol. Lo que consiste ya en transformar una subordinación en afirmación y por eso mismo comenzar a burlarla" (Irigaray 1982: 73). Es cambiar el juego especular del discurso, donde la mujer pierde su identidad y se convierte en un reflejo, para iniciar la "especulación" y "especular", es decir, mirarse para mirar.

Las teóricas norteamericanas Sandra Gilbert y Susan Gubar, en su texto La loca del desván, hacen una propuesta interesante sobre la autoría femenina a partir de su marginalidad. Inician diciendo que "...la pluma del poeta es en cierto sentido (incluso más que de forma figurada) un pene" (1998: 18), con lo que establecen la producción literaria como un ámbito exclusivo de lo masculino. Así, la realidad es el producto del verbo de un dios padre creador (Dios-patriarca-autor) que ejerce su dominio en ese mundo suyo (universo-polistexto). Es una jerarquización que asegura el poder, donde incluye (lo masculino) y excluye (lo femenino). Sin embargo, la "maternidad" como hecho biológico rompe con la creación de la sociedad patriarcal. Por lo que la "paternidad", a falta de lo material-tangible crea lo simbólico-intangible, para dar cuenta de su perpetuación. Esto tiene relación directa con la literatura, pues la mujer también se constituye en una formulación masculina, sin voz, sin acción, y sin identidad. La mujer no tiene procesos de identidad, porque carece de lo que ella dice y piensa de sí misma, por eso lo que posee es crisis de identidad.

¿Qué significa, entonces, que una mujer asuma la pluma? Pues, entre otras cosa se ve como la imitación pobre de lo masculino. También es “...una intrusa y una criatura presuntuosa, (...) es absolutamente irredimible” (Gilbert y Gubar 1998: 22), su palabra será débil y anómala o impotente.

La autora está sujeta al mismo modelo patriarcal que el autor. Se constituye en sujeto, pero se da cuenta que su imagen es ajena, es fragmentaria. La autora se autoafirma, dice "yo soy", "yo quiero" y "yo deseo"; y esto le es prohibido, por lo que se le descalifica con denominaciones como de loca, irracional, esquizofrénica. En la escritura, “...las mujeres no sólo han estado excluidas de la autoría, sino que además han sido sometidas a (y sujetas de) la autoridad masculina" (Gilbert y Gubar 1998: 26). En este sentido, se plantea que la autora ha buscado paliativos a este aislamiento social, siendo la imagen de la locura y del encierro algunas de ellas. Es decir, la autora conjura los calificativos que socialmente se le imponen para descalificarla, pero con eso los niega, los nombra para liberarse de ellos.

En esa medida, la mujer escritora, antes de ir hacia la autonomía literaria “...debe aceptar las imágenes de la superficie del espejo, es decir, esas máscaras míticas que los artistas masculinos han fijado sobre su rostro humano..." (Gilbert y Gubar 1998: 31). 


\section{El discurso especular femenino}

De acuerdo con Gerard Imbert, el concepto del "otro" puede poseer tres formas: Un "otro virtual", que consiste en la forma no realizada del sujeto; un "otro marginal", que es residual, el lado negativo, o la otra cara; y finalmente, un "otro anti-sujeto", que cuestiona al sujeto desde dentro (1990: 59-60). La mujer estuvo excluida de la posición subjetiva, y por ello no tuvo posición enunciativa; no se ve como una posibilidad de realización del sujeto masculino, ni como algo que pueda desarticular el discurso patriarcal en su totalidad; es decir se constituye socialmente como otro marginal. Tradicionalmente, ha sido un sujeto del que se habla y no un sujeto que habla. Consecuentemente, la feminidad no ha tenido un proceso de identidad ("lo que la(s) mujer(es) dice(n) de sí misma(s)"), sino lo que posee es una crisis de identidad.

Rosa Montero plantea en su novela esa búsqueda para encontrar el lugar de lo femenino en la sociedad. Las protagonistas procuran recuperar su papel social en esa cambiante y amenazante urbanidad. Son sujetos que oscilan entre la tradición y las nuevas propuestas éticas. Son mujeres atrapadas en el espejo de la representación social de sus roles. No siempre se tratará de cánones tradicionalmente asignados, puede referirse a nuevos valores del papel femenino: "Y sabe que saldrá y será encantadora, inteligente, divertida y amable, que representará con sabio hábito su papel de mujer fuerte y libre, ni exigencias ni lágrimas que son deleznables y femeninos defectos. "Eres una mujer maravillosa", dirá él en el momento de la cena con entonación admirativa y lejana -como quien elogia un vino fino, una sonata amable, esas delicadas cosas que hacen más grata la existencia" (Montero 1999: 11), todo eso lo piensa el personaje de Ana, y corrobora que siempre se trata del tipo de mujer que la sociedad patriarcal determine conveniente a sus gustos, sus necesidades, su placentera y grata existencia. Una mujer que no estorbe o entorpezca su vida, que se amolde a sí, sin exigencias, ni gritos, un objeto más que un sujeto.

Crónica del desamor expresa una profunda reflexión en torno a la identidad de la mujer, y revisa el papel socio-cultural tradicional que le ha correspondido desempeñar a lo largo de los tiempos: “...vivía supeditada a él, intentaba borrar, quemar los días que me separaban de sus citas. Una tarde me encontré con treinta años y quedé horrorizada: cómo era posible que estuviera permitiéndome tirar así mi vida por la ventana, sin aprovechar mis días hasta el máximo. (...) Proyectas los deseos de felicidad en un hombre, o en que te toque la lotería, o en conseguir una casa mejor, o en lo que sea, no importa qué, con tal de que te desvíe el futuro la responsabilidad de ti misma" (Montero 1999: 129).

Esta clara interrogación acerca del lugar de lo femenino, se plantea en la novela bajo un tono de profundo desengaño, que se observa desde el título. Es una crónica, una historia en orden temporal, marcada por la falta de amor: el desamor. Aunque implica el concepto de unión o separación de parejas, va más allá de la enunciación romántica de este tópico literario. Es un texto que implica la relativización de las relaciones humanas, donde la falta de fiabilidad en la sociedad se refleja en lo interpersonal.

Crónica del desamor mantiene ese tono íntimo de ensimismamiento reflexivo, que va decodificando el signo mujer. Un ensimismamiento descreído hacia los demás, a causa de una experiencia histórica de aislamiento, que ahora se unifica con la confabulación de una situación urbana aturdidora. Se instaura la sociedad de extraños, la gran ciudad que lleva al aislamiento del individuo. El egoísmo mezquino que representa la desintegración social: "Se perdió la relación grupal y permeable de los barrios, y ahora las ciudades se ven sujetas 
al exilio interior, a la peregrinación urbana: no se vive en la misma casa que naciste, te desperdigas por una ciudad antropófaga y enorme intentando conservar las viejas amistades, separadas de ti por muchas calles" (Montero 1999: 212), unido al desencanto social que viven la mayoría de los sujetos humanos; pero, en la mujer se acrecienta al despertar del extenso letargo, y reconocerse sola, cercenada en su situación de persona, marginada. Recapitula así, una serie de temores como la soledad, acontecimiento inminente, o la ancianidad, inevitable decrepitud de la existencia: “...lo peor será cuando estemos solos, nosotros, que vivimos solos, que envejeceremos separados, que con los años iremos perdiendo poco a poco la capacidad de salir y de movernos, la posibilidad física de ayudarnos y encontrarnos, que poco a poco, al compás de las arrugas y los primeros dolores artríticos o reumáticos, nos iremos encerrando en nuestras cuatro paredes, cada día más irreversiblemente consumidos" (Montero 1999: 68).

La escritora expone ese despertar amargo del sujeto femenino, donde reconstruye el camino de su aislamiento social y personal, “...porque la mujer es un caso aparte: no se le ofreció poder a cambio de su represión, sino que ésta fue utilizada en función del hombre" (Montero 1999: 80), donde carece de poder sobre lo que le rodea, y más aún, sin poder sobre sí misma. Si socialmente los hombres fueron castrados en nombre del poder, la mujer sufrió una doble castración, por el poder y por el hombre.

Rosa Montero también procura en su texto el proceso de aprendizaje, donde el individuo va aceptando la mediocridad del entorno, sólo que en una búsqueda de verificación de su propia existencia. Es una revisión de los discursos sociales tradicionales, pues la mujer atrapada por el hombre en zonas específicas del discurso logocentrista, sigue arrastrando esos cánones prediseñados para ellas hasta su inconsciente, como se evidencia en el sueño de Candela sobre su madre: La mujer como esposa (“...un matrimonio feliz. Casi cuarenta años desde que me casé a los veinte, virgen y niña"), la sumisión de su rol ("Los primeros diez años lloré un poco por las noches, en secreto, o bien en las mañanas con la casa sola, sentada en una cama a medio hacer..."), la rutina de su encierro doméstico ("Me acostumbré a ir quemando los días, esperando la noche, reventada de cansancio y de rutina...”), la dependencia emocional (“...llegó un momento en que me sentía incapaz de afrontar el mundo exterior...”), la minimización por parte del esposo-dueño (“Tú eres tonta, me decía tu padre al verme tan inútil...”), la represión de su cuerpo y su sexualidad ("Hace tan solo cuatro años, tras leer un libro de iniciación sexual de tu hermana la pequeña, conseguí el primer orgasmo..."), y la mutilación de su derecho a la palabra, de su derecho a decirse (“...y Candela observó con espanto que en la boca abierta de su madre florecía el herido muñón de la lengua de Margarita, y entre las carcajadas de Antonia resbalaban cuajarones de sangre amoratada") (Montero 1999: 203 y 204).

Se retoma la educación tradicional de la mujer, para ser cuestionada, refutada e impugnada, pues sólo se les preparaba para ser parte de una pareja en realidad dispareja: “...la verdad es que hemos tenido una educación repugnante al respecto, ¿os acordáis de esos libros lamentables que leíamos en nuestra adolescencia, eso del Diario de Ana María y Daniel? Bueno, pues Ana María llevaba por subtítulo la palabra Dar, y el libro de Daniel llevaba la palabra Amor (...) exacto, con esa mierda de diarios nos querían ir educando en nuestro papel correspondiente, las mujeres a Dar, o sea, a ceder, y los hombres a Amar, o sea, a perdonar, a dirigir con suave, es decir, con suave mano paternal, a brillar como centro de la Creación" (Montero 1999: 96).

La mujer toma conciencia de su secundariedad social, de su suplementariedad en relación con el sexo fuerte; y esto es lo que les permite acceder a la palabra, a la enunciación 
de quiénes son ellas y qué es lo que buscan, en un asumirse para asumir. Es un texto que busca constantemente la redefinición de la identidad a partir de la alteridad, de lo vedado "un retorno a lo reprimido histórico, en el resurgimiento de una alteridad mágicamente negada..." (Imbert 1990: 57). Crónica del desamor retoma aquellos temas tabú: la llamada liberación sexual, o época del destape, pero para descubrir una amalgama de relaciones sociales más que sexuales. Busca algo más que el intercambio de placer sublimado, busca la palabra.

La prostitución y la homosexualidad, como ejemplificación de este proceso, descubren los linderos de un desengaño personal: “...esta torturada espera homosexual, no es más que el último símbolo, el más patente, del desencuentro de todas las relaciones, del hundimiento de la fe en la pareja. Hay que esperar" (Montero 1999: 118). Es una introducción de temas desterrados del discurso social (aborto, divorcio, etc.), que a la vez permiten una revisión de los roles socio-culturales.

La mujer incursiona en el discurso de los excesos, donde trata de desatar lo que más evidentemente le fue negado y reprimido, su propio cuerpo. Hace pública su vida sexual, sus necesidades biológicas, y su nueva forma de vida. Su sexualidad deja de ser parte estricta del orden privado, como hecho más que simbólico de que ha dejado ese aislamiento de su persona, esa reclusión en el espacio doméstico, único espacio propicio para ella hasta entonces.

La feminidad se va introduciendo en los lugares públicos que le eran prohibidos, tal es el caso de los bares. Ana, la Pulga, Elena, Olga, Candela, buscan aquí el intercambio social que les fue censurado, y que sólo era realizado por el patriarca protector (padre, esposo o hermanos): "El hacer se inscribe en un recorrido figurativo: espacios abiertos que representan un peligro..." (Imbert 1990: 85), pero ante todo, esa incursión refleja la búsqueda del reconocimiento de su existencia, de su identidad: "De modo que se acerca al pub de Mercedes y Tomás, a Galáctica, que está como siempre lleno a rebosar, es un local pequeño con aire espeso y ponzoñoso” (Montero 1999: 103), “...aquí estamos las dos encerradas con nuestras neuras, se dice, yo con mi obsesión de siempre y la Pulga intentando entretenerme con su charla para que el momento de su vuelta a casa se retrase lo más posible" (Montero 1999: 106). Sin embargo, no es un gran logro, ya que sólo parece cambiar la cara del encierro, de un claustro material a otro emocional o psicológico, y esto hace recapacitar a los personajes sobre una situación que no cambia, un círculo que las atrapa. Siempre aunado a la amargura de la soledad urbana que igualmente las absorbe, mutila, y hasta las deshumaniza.

Crónica del desamor representa una interesante metáfora de esos lugares de refugio urbano, donde grupos marginales (prostitutas, drogadictos, homosexuales, mujeres...) se amparan y protegen entre sí. Galáctica, el bar de Mercedes, se análoga con el útero materno, protector y femenino: "Las primeras horas son de reconocimiento, pues, y luego ha de empezar el largo viaje que en realidad es muy corto, no hay más que seguir el cordón umbilical (...) Algunos se van y otros vuelven, en un reencuentro con el grupillo que es casi útero materno, con la gente que es tu gente, núcleo de protección para marginados y protegidos, grupúsculo revolucionario de miserias..." (Montero 1999: 154). Pero, es un lugar marginal con seres marginales en una dolorosa búsqueda de la supervivencia, lo cual reafirma esa marca de la feminidad disminuida, menospreciada. No se plantea un cambio real para la mujer, sólo aparente, pues sigue en la misma esfera social: la inferioridad.

La mujer también incursiona en el espacio laboral, y el texto de Montero reflexiona sobre esa faceta de trabajadora asalariada. Así, se descubre nuevamente su papel supeditado y absolutamente secundario: "Como cuando le echaron del banco por quedarse embarazada (...) no vamos a dejarla en la calle, se le dará una compensación económica, se le pagará el sueldo hasta 
que usted dé a luz y además el Banco correrá con los gastos de hospital (...) se le nota mucho ya, ¿sabe?, se atrevió a susurrar en un vergonzoso aparte (...) él, claro está, tenía siete, u ocho, o nueve hijos, quién sabe la cifra exacta, una manada de hijos bendecidos, legales, religiosamente concebidos sin placer" (Montero 1999: 236 y 237). El hecho es que a la mujer se le perdona que trabaje, pero no que asuma un rol de independencia total. La maternidad es digna si se realiza bajo los cánones establecidos (el matrimonio), de lo contrario es castigada socialmente.

Por otra parte, aún cuando Ana realice un trabajo periodístico igual al de sus compañeros, sigue considerándosele inferior: "Y claro, una mujer sólo puede dedicarse a escribir chorradas" (Montero 1999: 237). Continua la marginación laboral para aquellas mujeres que cometan la imprudencia de optar por una labor exclusiva del hombre, sea a nivel físico o intelectual.

Las mujeres de Crónica del desamor reconocen su condición social pasada y presente, como un primer paso para reencontrarse ellas mismas. No subvierten sólo exponen y refutan, desarrollando un verdadero discurso especular. Ya no son personajes atrapados al otro lado del espejo, sino que usan ese juego de especulación y especularización, de mirarse a sí mismas para mirar el entorno.

La novela de Rosa Montero reconoce con profundo sinsabor la condición femenina marginal de una sociedad patriarcal. No trata de obviar lo obvio creyendo todo el discurso de la liberación, más bien profundiza en la relaciones sociales. Pero, no para quedarse sólo en eso, avanza un poco más en el descubrimiento de su propia identidad, y en la búsqueda de la formulación de una imagen propia de sí:

\footnotetext{
Quizá es que durante mucho tiempo ha confundido la liberación de la mujer con el desprecio hacia la mujer misma: la liberación pasaba por la mimetización con el sexo del poder, había que adoptar valores masculinos, copiar al hombre, repudiar la identidad de hembra. Elena, ahora, ha descubierto en su cuerpo el orgullo de saber que puede parir, si quiere, y que esto no es una servidumbre. Ha descubierto el orgullo de reencontrarse como sexo (Montero 1999: 207).
}

\section{Autoafirmación del discurso autoral femenino}

Durante mucho tiempo la escritura ha sido un acto eminentemente masculino. En la producción literaria se ha asumido la pluma como una extensión metafórica del pene masculino, único símbolo de poder. Retóricamente se ha desarrollado toda una homología paternalista para reafirmar este postulado ideológico:

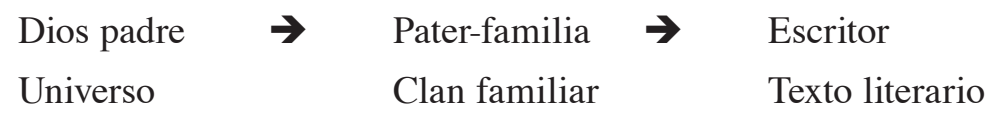

El escritor se constituye en una autoridad (fundador) que fija la ley como el paterfamilia, mediante la palabra, y como Dios asume el verbo para crear su universo (Gilber y Gubar 1998: 17- 20). De esta forma, si la mujer pertenece al hombre es porque él la ha originado; todo lo femenino será una formulación masculina. Ella es inacción, carente de verbo, nunca sujeto que nombra. Ha sido enunciada y fabulada a través de la mirada masculina, y de ahí que se presente el universal de la subordinación femenina: hombre es el centro/mujer es el margen. El logos, la palabra, es propia de la masculinidad; pues sólo ahí se da la voz: "Soto Amón es hombre acostumbrado a hablar y a callar a los demás, y parece haber perdido la capacidad de escucha" (Montero 1999: 241). 
En la novela de Rosa Montero descubrimos a una mujer asumiendo la pluma, en una autoría femenina que se considera copia, inautenticidad, intrusa o presunción, ya que la voz es el hombre y la mujer es silencio. Por ende, toda mujer que transgreda la imagen, o la máscara que se le ha asignado en la sociedad patriarcal, es merecedora de castigo, bajo la concepción religiosa del pecado, y se le impone la tachadura de loca, descabezada e irracional.

En Crónica del desamor, el discurso autoral invierte y altera el orden preestablecido. El discurso de la autoría asume su locura o esquizofrenia, pero no para afirmar el discurso falocéntrico, sino para negarlo. Usa paliativos que le ayudan a confrontar lo establecido, y a reencontrarse ella misma. Por consiguiente, observamos un desdoblamiento de la autoría en dos personajes: Olga y Ana.

En primera instancia, Olga corresponde con la loca, la descarriada mujer que decide autoafirmarse y decir "yo soy", "yo quiero" y "yo deseo". Son palabras y actos prohibidos en una mujer, ello le lleva a la marginación y al azote social: "No aguanto más esto, Ana, en mi oficina son unos hijos de puta, me explotan, me matan, me revientan, me odian porque no soy como ellos (como ellos quieren que sea), porque tengo ojeras de vida nocturna, porque no llevo sujetador, porque estoy viva. Mierda de mundo, me iré de aquí, Ana, me iré y no volveré más" (Montero 1999: 157).

Olga desafía el patriarcalismo y debe sufrir las consecuencias, inicia un viajebúsqueda sin retorno hacia su propio aislamiento: "Se estaba poniendo muy rara Olga, sabes, muy rara. Es que India es una experiencia muy fuerte, tan fuerte que mucha gente se queda ahí, sabes lo que quiero decir, se queda y no vuelve, no vuelve a ella misma" (1999: 159). Su completo aislamiento es, finalmente, el castigo dado a su enorme pecado, y entra en el plano de las tinieblas, el lado oscuro, la bruja, el "deber evitar" del discurso logocéntrico: "Así estaba Olga cuando la dejé, pasando la frontera hacia la nada, pasándola con una gente muy siniestra que había conocido..." (1999: 160).

La mujer-loca busca la evasión de su propio encierro emocional y social, y la autora la conjura para liberarse de esa marca. El discurso autoral nombra a la loca -pleno reflejo de sí dentro del patriarcalismo literario predominante- para finalmente dejarla, negarla y liberarse de ella. Es el mal-estar de la autora que señalan Gilbert y Gubar, donde la escritora debe asumirse a pesar de los calificativos de loca; y que además procura darle a su escritura un lugar propio, ya que la literatura ha sido por tradición, masculina:

\footnotetext{
...para curarse, la escritora, en primer lugar, debe exorcizar las frases que incuban su contagio; debe liberarse franca o encubiertamente de la desesperación que inhala de algún "Hacedor ajado", y que sólo puede hacerlo revisando los textos del Hacedor (1998: 90).
}

Un segundo desdoblamiento, el más evidente quizá, se presenta en la figura de Ana. En un mundo masculino, el texto de Rosa Montero plantea la autoría femenina desde el ámbito femenino, autoafirmándolo y dándole una identidad propia. Este hecho autoral se comprueba cuando descubrimos que la virtual escritora es, precisamente, Ana: "Piensa Ana que estaría bien escribir un día algo. Sobre la vida de cada día, claro está. Sobre Juan y ella. Sobre el Curro y ella. Sobre la Pulga y Elena. Sobre Ana María (...) Sobre manos babosas, platos para lavar, reducciones de plantilla, orgasmos fingidos, -llamadas de teléfono que nunca llegan, paternalismos liberales, diafragmas, caricaturas y ansiedades. Sería el libro de las Anas, de todas y ella misma, tan distinta y tan una" (Montero 1999: 10). 
Es en principio, una escritura desde lo privado, lo rutinario, lo cotidiano, lo doméstico: sus amigos, problemas, inquietudes y afectos. Es decir, desde el encierro femenino, ensimismamiento obligatorio a causa de una estructura que la aliena a ello, a mirar hacia adentro, porque ella es adentro, lo uterino, la caverna que se pliega sobre sí misma. También, es una búsqueda de las feminidades, ya no sólo de ella misma, sino del lugar femenino, de las Anas, las mujeres, las que son como ella.

Es una escritura liberadora pero amarga, pues debe recorrer de su situación histórica. Es un mal-estar en la autoría al descubrir su situación suplementaria, marginal y a veces caótica. Por eso, es una escritura con furia: “...hubiera sido decididamente inaguantable de no haber utilizado esas largas horas solitarias en escribir con furia, en llenar folio tras folio con fragmentos inconexos del pasado" (Montero 1999: 134).

Ana hace una revisión total de su pasado, tal vez para descubrir quién es ella ahora, y dice que “...le es más fácil escribir sobre el pasado que aventurarse al futuro" (Montero 1999: 136). Así va develando el prolongado letargo de sumisión, marginación, represión de su sexo y su género. Descubre los temores escolares ante las acechanzas de los hombres libidinosos que la seguían; el acoso de los jefes cuando iba a conseguir trabajo; la "lucha de guerrilleras" infantiles por superar el "hambre de sexo de los trabajadores"; hacer de oídos sordos ante los infames insultos en las calles; el amedrentamiento, la culpabilidad; y finalmente la pérdida paulatina de la inocencia pueril en el descubrimiento de un mundo masculino del que son repelidas y cosificadas (Montero 1999: 138-145).

Ana confirma el hecho de que ahora es ella quien escribe, quien se asume, quien habla y toma la palabra para decirse. Es ella la que en el acto de escribir va definiendo su papel de autora, productora del texto, de su vida, de su identidad. Aún cuando su acto voluntario no reciba el reconocimiento de los demás, y mucho menos de los pequeños patriarcas: "Estoy escribiendo, contesta Ana, ¿por qué?, porque me gusta, añade ella mientras le abraza. Pero el Curro calla un momento mirando las hojas cubiertas de menuda letra, luego se deshace del abrazo, joven, cruel y poderoso, y ya en el suelo, comenta con tajante y sabio tono: pues es una tontería" (Montero 1999: 147 y 148).

La escritora, en Crónica del desamor, recurre a los monólogos internos, es decir a lo reprimido en ella, y logra expulsarlo al exterior. Busca dentro de sí, en su ensimismamiento, para interrogarse e interrogar al entorno acerca de su lugar. Ana refuta con sus observaciones la hipocresía de la sociedad, descubriendo una doble moral en torno a su situación: “...parecería que en esta sociedad ambiguamente liberal se admite la existencia de la soltera que es madre de un hijo. Pero si la soltera reincide, si la mujer insiste en su desorden, obcecada, si se atreve a tener más hijos de diferentes padres y pretende aún así permanecer independiente, entonces, ah, entonces se convierte en caso inadmisible, "esta pobre Candela", empiezan a decir con voz meliflua, "que desastre de vida", añaden, arrugando sus escrupulosas narices con gesto de desagrado" (Montero 1999: 197).

En el discurso autoral es la mujer la que se prefigura como observadora del hombre. Es la mujer mirando y diciendo del hombre, e invirtiendo el juego añejado de la literatura paternalista.

Ana asume la mirada tan ajena a ella -la mirada masculina-, e incluso con la sabiduría del tiempo cíclico, rutinario, de su encierro, anticipa todas las situaciones de su inminente encuentro con Soto Amón: "Y con entristecida certidumbre, Ana intuye en un segundo el desarrollo de la noche, él me desnudará con mano hábil y ajena, simularemos unas caricias vacías de intención, nos amaremos sin decir nada en un coito impersonal..." (Montero 1999: 243), luego dice: "Se 
desarrolla, pues, la pantomima con asombrosa semejanza a lo previsto (...) todo un año que se acaba ahora en esto, si él supiera..." (Montero 1999: 244).

La autora enuncia un discurso desde lo establecido patriarcalmente, pero en ello descubre su propia identidad. Incursiona en el discurso patriarcal, pero para desestabilizarlo. Ana descubre que el denominado narcisismo de la autoría es porque ella se asoma al espejo, pero, paradójicamente ella es el espejo de la narcisista visión masculina. Efectivamente, Anaescritora siente la seguridad de haber descubierto algo, que puede ser ella misma, su identidad como autora, y que posiblemente será lo que le facilite un inicio, un empezar a hacer y decir:

\begin{abstract}
Un gesto cruel y poderoso que, quién sabe, recapacita ella con ácida sonrisa, puede ser un buen comienzo para ese libro que ahora está segura de escribir, que ya no será el rencoroso libro de las Anas, sino un apunte, una crónica del desamor cotidiano, rubricada por la mediocridad de ese nudo de seda deshecho por la rutina y el tedio (Montero 1999: 246).
\end{abstract}

\title{
5. Conclusiones
}

El estudio de la novela española, Crónica del desamor de Rosa Montero, nos permite destacar algunas consideraciones finales. Se retoman así, los ejes fundamentales del recorrido:

En la novela de esta escritora española, se descubre un discurso especular femenino que interroga acerca de su identidad, en un entorno que la ha marginado históricamente. Descubre que en la bipolaridad mismidad/ otredad del proceso de construcción de la identidad, lo femenino ha ocupado siempre el lugar de la alteridad dentro del sistema patriarcalista, sin derecho a la autoimagen y la autoconstrucción. Esto conlleva un mal-estar que se evidencia en el descreimiento personal acerca de las relaciones humanas, y particularmente, de las relaciones de pareja; así como un asumir lo otro vedado (discurso del exceso: temas tabú, incursión en los espacios públicos, etc.) para deshacerse de su propia sujeción material, emocional y sicológica.

Esa reflexión implica la deconstrucción paulatina del juego del lenguaje (patriarcal), al plantear las ambigüedades que fracturan las relaciones entre la teoría y la praxis del discurso de la liberación de la mujer. De manera que, se constituye una pérdida de la fiabilidad, al emerger la transposición de una clara ambivalencia.

En el texto de Rosa Montero, se presentan por su parte, dos elementos característicos de la autoría femenina: la loca y el encierro (ensimismamiento), en los personajes de Olga y Ana. Ambos elementos son propuestos por Gilbert y Gubar, y se refieren a una forma de asumirse la autora como sujeto creador. Son elementos que la tradición falócrata asigna a la mujer escritora para restringirla y aprisionarla, pero que ella conjura en su novela para desvirtuarlos, y en forma ritual, ascender a su propia autoafirmación creadora.

En síntesis, se puede decir que respondiendo al período de transición socio-política que vivía su país en el momento de la producción del texto (1979), la novela Crónica del desamor representa con claridad algunos de los postulados más importantes de dicho momento. Por un lado se relativizan los discursos sociales asociados al comportamiento de los individuos (particularmente de la mujer), se da una pérdida de la fiabilidad en ellos, y un consecuente pesimismo existencial reflejado en el entorno de la pareja. Todo ello lleva a una visión femenina desencantada de la realidad, con una crisis de identidad que se orienta hacia la búsqueda interna de su propio "yo" (no el impuesto por el patriarcado), y externa, de su lugar dentro de la estructura social. 


\section{Notas}

1. Abogado y político español, que vivió de 1903 a 1936. Fundador de la Falange Española, que sirvió de base al franquismo. Fue fusilado en Alicante.

2. Agrupación política fundada por José Antonio Primo de Rivera en 1933, fusionada en 1934 con las J.O.N.S.(Juntas de Ofensiva Nacionalista) y unificado en 1937 con el Tradicionalismo para formar la Falange Española Tradicionalista y de las J.O.N.S.

\section{Bibliografía}

Bosch, Esperanza et al. 1999. Historia de la misoginia. Barcelona: Editorial Anthropos.

De Beauvoir, Simone. 1980. Obras completas. Tomo I. Traducción: Juan Gacía Puente. España: Editorial Aguilar.

Giddens, Anthony. 1999. Consecuencias de la modernidad. Madrid: Editorial Alianza.

Gilbert, Sandra y Susan Gubar. 1998. La loca del desván. Madrid: Editorial Cátedra.

Glenn, Kathleen M. 1995. "Las cartas de amor de Carme Riera: El arte de seducir". En: Del franquismo a la posmodernidad. Cultura española 1975-1990. Edición a cargo de José B. Menleón. Madrid: Editorial Ahal.

Imbert, Gerard. 1990. Los discursos del cambio: Imágenes e imaginarios sociales en la España de la transición (1976-1982). Madrid: Editorial Akal.

Irigaray, Luce. 1982. Ese sexo que no es uno. Madrid: Editorial Saltes.

2000. "Una mirada vacía". En: //Libazar.ipg.811944byles/Libreríavirtual.htm. Consultado el 2 de mayo de 2001.

Lyon, David. 1997. Posmodernidad. Madrid: Editorial Alianza.

Miñana, Rogelio. 2000. "Rosa Montero". Consultado el 16 de mayo de 2001. En: //interview. e/Interviews with Spanish womens and men.htm.

Moi, Toril. 1995. Teoría literaria feminista. Madrid: Editorial Cátedra.

Montero, Rosa. 1999. Crónica del desamor. $4^{\mathrm{a}}$ ed. Barcelona: Plaza y Janes Editores.

Mora E., Sonia et al. 1995. "El segundo sexo: La segunda literatura”. En: Káñina, 9 (2): 19-24. 
Navajas, Gonzalo. 1996. Más allá de la posmodenidad: Estética de la nueva novela y cine españoles. Barcelona: Editorial EUB.

Ordóñez, Elizabeth J. 1995. "Escribir contra el archivo: Nueva narrativa de mujer”. En: Del franquismo a la posmodernidad. Cultura española 1975-1990. Edición a cargo de José B. Menleón. Madrid: Editorial Ahal. 